\title{
The 1st International Symposium on Business Corporation and Development in South-East and South Asia under B\&R Initiative(2016) Analyzing the Business Case for the China-Pakistan Economic Corridor
}

\author{
Jabin T. JACOB \\ Assistant Director \& Fellow, \\ Institute of Chinese Studies, Delhi \\ Kunming, China \\ jabinjacob@gmail.com
}

\begin{abstract}
There are two key issues ignored in the discussion around the China-Pakistan Economic Corridor (CPEC) by analysts from out of China and Pakistan who tend to focus on its so-called 'strategic' or military objectives. The first is of the level of employment that will be generated by the CPEC. The second, given the CPEC's focus on energy infrastructure, is of whether the addition to Pakistan's energy capacity is really necessary and, if necessary whether it will resolve the problem of the country's problems on the energy front.
\end{abstract}

Keywords-economic development; employment, infrastructure development; energy sector' energy pricing

\section{PAPER}

The announcement of the China-Pakistan Economic Corridor (CPEC) by Chinese president Xi Jinping in 2015 introduced greater levels of complexity to a bilateral relationship hitherto based mostly on military exchanges and diplomatic partnership. From any objective point of view it would seem that the CPEC's implications not just increase the intensity of the Sino-Pak relationship but also convert it into a fundamentally new relationship.

The huge sums involved - US\$46 billion as announced, including some US\$34 billion in energy projects alone, indicate the dire straits that Pakistan's economic development is in and the Chinese have identified and targeted correctly those areas most critical to ensuring Pakistan's political stability. China's promised infrastructure investments 'nearly equal' the amount of foreign aid the US has provided to Pakistan over the past decade in support of its war efforts in Afghanistan.

\section{A NEW PHASE OF THE RELATIONSHIP}

The details of the CPEC, including layout, alignment of routes, figures for investment are now available widely in the public domain even if some these data do not always match and information is not available in one place or even not at all [1].
Pakistani global exports have also been declining for a variety of reasons, among which is that the energy crisis has significantly reduced the textile industry's production capacity, especially in Punjab. According to Chinese reports, Pakistan needs as much as US\$20 billion in investments over the coming five years to overcome a $10,000 \mathrm{MW}$ shortfall in power capacity. These figures indicate the dire economic development straits that Pakistan finds itself in and full credit to the Chinese for identifying and targeting these areas as critical to ensuring Pakistan's political stability. A ' $1+4$ ' Sino-Pak cooperation structure has been envisaged with the CPEC at the center and the Gwadar Port, transport infrastructure, and energy and industrial cooperation being the four key areas. Chinese Overseas Port Holdings Ltd, a subsidiary of China State Construction Engineering Corporation has been granted the right to operate Gwadar for 40 years. 2,231 acres of land have been acquired to establish free-trade zones near the port and a 23-year tax holiday declared for Gwadar.

China's promised infrastructure investments 'nearly equal' the amount of foreign aid the US has provided to Pakistan over the past decade in support of its war efforts in Afghanistan. During Xi's visit to Pakistan, some US\$28 billion worth of agreements were signed to build roads, ports and power plants. However, projects started taking off well before the visit. For instance, Prime Minister Nawaz Sharif broke ground for a section of the $60 \mathrm{~km}$-long four-lane fenced Hazara Motorway in Khyber Pakhtunkhwa province, expected to cost US\$297 million.

Meanwhile, a crucial question left out of discussions on the CPEC is about economic viability of it all. There are no open source studies from either Chinese or Pakistani scholars on the subject currently available which look at the issue in detail or comprehensively. Pakistani scholars have noted several times the lack of transparency surrounding the project and have called for more details to be put in the public domain. There is not a little concern about the exact terms of the contracts signed, for instance. It is freely admitted, for instance, that Pakistani economists do not have enough data to work with to figure out 
The First International Symposium on Business Cooperation and Development in South-East and South Asia under B\&R Initiative (ISBCD-16)

the viability of the CPEC, the employment generated at home and so on.

\section{EMPLOYMENT}

An important aspect of the CPEC that will determine its success as well as long-term implications is of the level and kind of employment it will generate for Pakistanis. Speaking specifically in the context of the CPEC, Ahsan Iqbal, Federal Minister for Planning, Reform and Development, noted that Pakistan needed to grow at 7-8\% annually in order to create one million jobs annually [1]. So there are high expectations but the figures for employment to be generated for civilian Pakistanis by the actual projects of the CPEC, has been far from clear.

While Chinese news reports talk of the CPEC directly creating more than 10,000 jobs, [2] with the Chinese ambassador to Pakistan, Sun Weidong declaring that 'As of March 2016, ongoing CPEC projects have employed more than 6,000 Pakistanis,' [3] there is also talk that much of the labour especially in the skilled category and managerial positions will be Chinese. One Chinese media report puts the current number of Chinese engineers and technicians involved in the construction of about 210 projects in Pakistan at some 14,000.4 In any case, 10,000 Pakistani jobs seems too small a figure even if one were to assume that only a few billions of the US $\$ 46$ billion promised by the Chinese have been invested.

The most frequently cited figures for Pakistani employment come in the security domain. One Pakistani news report says a force of about 15,000 personnel has been raised to protect the Chinese investment and its citizens [5]. Another source states that the Special Security Division (SSD) promised by Pakistan Army chief Gen. Raheel Sharif will recruit some 18,000 personnel6 while Pakistani Minister of State for Interior Muhammad Balighur Rehman declared in the Senate in June 2016 that recruitment was already underway and 3,000 personnel already hired [7]. In addition, additional wings of Civil Armed Forces are also likely to be raised to guard ongoing CPEC projects [8].

Elsewhere, while one report states that Gwadar is expected to deploy 700-800 policemen in 'an independent security department, specifically to protect the safety of Chinese people' [9], another notes that even a single Chinese citizen in Gwadar requires a security detail comprising police, paramilitary and army personnel, in addition to several vehicles as part of the entourage [10].

These figures both reinforce the notion that a large number of Chinese will be employed and also that local employment on the projects themselves - at least in certain areas like Balochistan are likely to be limited or constrained by factors such as security. Further, if as a Global Times interview with Ahsan Iqbal, Minister of Planning, Reform and Development in Pakistan and in charge of the China-Pakistan Economic Corridor, notes 'Chinese products, by relying on their competitive advantage, could impact Pakistani brands'[11], then there are still more Pakistani jobs that could be lost as a result of the ingress of Chinese products. Already, Pakistani reports on the impact of the Pakistan-China FTA note the stress that this has placed on Pakistan's domestic industries. One news report cites a figure of 20,000 jobs in the shoe-manufacturing sector alone, having moved from Pakistan to China [12].
The other issue ignored in the discussion around the CPEC and its focus on energy infrastructure, which is of whether this CPEC addition to Pakistani energy capacity is really necessary or even if necessary whether it will resolve the problem of the country's energy problems.

According to Chinese reports from 2015, Pakistan needed as much as US\$20 billion in investments over the coming five years to overcome a $10,000 \mathrm{MW}$ shortfall in power capacity [13]. Another assessment by the ADB, too suggests Pakistan has an energy crisis but that this is expected to end in two years [14]. A more recent figure for Pakistan's installed capacity and of what is being planned in terms of additional capacity is $32,500 \mathrm{MW}$ and $21,500 \mathrm{MW}$ respectively.

According to an Indian analyst who cites a figure of 22,800MW for Pakistan's installed capacity and 19,000MW for the current demand -the problems is that Pakistan produces only 12,000MW.15 Another news report suggests that Pakistan has a demand for around $15,000-20,000 \mathrm{MW}$ but that it is able to produce only $11,500 \mathrm{MW}$ per day or, creating thus, a shortfall of about 4,000-9,000MW.16 However, distribution is just as critical a problem. Ahsan Iqbal, Pakistan's Minister for Planning, Reform and Development in 2015, pointed out that while the CPEC projects would produce a power surplus of $10,000 \mathrm{MW}$, Pakistan only had a capacity for distribution of 16,000MW [17].

The point is that Pakistan apparently has low production despite the available capacity and reason is circular debt - the Pakistani government pays power companies PkRs.15 per kWh and charges the consumer PkRs.10 but is only able to recover around PkRs.4.5 per kWh. In other words, the Pakistan government faces a shortfall of PkRs.10.5 per kWh, leading it either stop or delay payments to the power companies. The latter in turn are unable to pay for fuel supplies and so production declines. The current debt in the Pakistan energy sector stands at US\$5 billion [18].

On the subject of pricing of the power, one Pakistani scholar quoting 'some experts' said that power from CPEC projects would be available to the Pakistani consume at US cents 8-14 per $\mathrm{kWh}$ or PkRs1-2. These rates would be substantially lower than the prices currently being levied by Pakistan's power distributors as indicated above. So from Pakistan's point of view, these additional power projects make sense assuming that the terms of Chinese financing are reasonable too. However, this is far from clear.

For one, the terms of the CPEC contracts are not available in the public domain. It is to be noted that the Chinese have not provided grants or aid for CPEC projects but concessional loans. However, even these concessional loans are believed to cover only some US\$10 billion of infrastructure projects, according to one report [19] with export credit and non-reimbursable assistance by the China Development Bank, the Export-Import Bank of China, the Industrial and Commercial Bank of China Ltd. and other financial institutions believed to be backing the other projects [20].

Malik Ahmad Khan, a member of the Infrastructure and Regional Connectivity of Pakistan's Planning Commission revealed in September 2015 that China would extend assistance to Pakistan at $1.6 \%$ interest for CPEC infrastructure projects these are worth some US\$11.8 billion. He also said that Pakistan actually wanted the Chinese to reduce the rate further from $1.6 \%$ to $1 \%$ and that efforts were still on. The LNG pipeline in Gwadar being laid by the China Petroleum Pipeline Bureau is being 
The First International Symposium on Business Cooperation and Development in South-East and South Asia under B\&R Initiative (ISBCD-16) carried out under a loan from the Chinese government which covers $85 \%$ of the project cost with the Pakistani government putting in the rest [21].

The interest rates on these loans are believed to be lower than those that would be available from other institutions such as the Asian Development Bank or the World Bank, which also finance projects in Pakistan. Whether or not the Chinese have an equity in these projects, it is not clear how these will get around the problem of circular debt, or in other words, how they will resolve the problem of poor collection of dues from Pakistani electricity consumers.

\section{CONCLUSION}

In summary, there are serious issues on the economic front that China and Pakistan need to sort out in order to make the CPEC a success and beneficial for the people of Pakistan. Key among these will be the generation of adequate local employment in Pakistan and of affordable and regular power supply.

\section{ACKNOWLEDGEMENTSC}

The author wishes to acknowledge research assistance by Rishap Vats, Uddipta Ranjan Boruah, Rajesh Ghosh and Mayur Dandge.

\section{REFERENCES}

'http://www.thenews.com.pk/Todays-News-3-340846-Chinawants-Pakistan-to-benefit-from-its-development ${ }^{2}$ http://www.114junshi.com/news/123684.html

${ }^{3}$ http://news.xinhuanet.com/english/201606/24/c 135463588.htm

${ }^{4}$ http://news.meyet.com/article-170521-1.html

${ }^{5}$ http://tribune.com.pk/story/1085784/for-timely-completionarmy-seeks-role-in-cpec-administration/

${ }^{6}$ http://indiatoday.intoday.in/story/bomb-attack-in-pakistanchinese-engineer-injured/1/682582.html

${ }^{7}$ http://www.firstpost.com/world/pakistan-raising-17280-strongforce-to-guard-china-pakistan-economic-corridor-2832426.html ${ }^{8}$ http://uk.reuters.com/article/pakistan-china-security-gwadaridUKKCNOVH06F

${ }^{9}$ http://oversea.huanqiu.com/article/2016-02/8589836.html

${ }^{10} \mathrm{http}: / /$ www.wsj.com/articles/big-chinese-pakistani-projecttries-to-overcome-jihadists-droughts-and-doubts-1460274228

${ }^{11}$ http://www.globaltimes.cn/content/977489.shtml

${ }^{12}$ http://herald.dawn.com/news/1153413

${ }^{13}$ http://www.scmp.com/news/china/diplomacydefence/article/1772841/china-picks-pakistan-dam-first-stopus40b-silk-road

${ }^{14}$ http://mobile.reuters.com/article/idUSL8N19C3M4

${ }^{15} \mathrm{http}: / /$ www.thehindu.com/opinion/lead/theres-no-free-chineselunch/article7228058.ece

${ }^{16}$ http://dunyanews.tv/en/SpecialReport/320824-Power-and-Gasshortage-in-Pakistan

${ }^{17}$ http://www.thenews.com.pk/Todays-News-3-340846-Chinawants-Pakistan-to-benefit-from-its-development

${ }^{18}$ http://www.thehindu.com/opinion/lead/theres-no-free-chineselunch/article7228058.ece

${ }^{19} \mathrm{http}: / /$ www.reuters.com/article/us-pakistan-chinaidUSKBN0NA12T20150420

${ }^{20}$ http://www.icsin.org/uploads/2015/06/05/31e217cf46cab5bd9f $15930569843895 . \mathrm{pdf}$

${ }^{21}$ http://tribune.com.pk/story/965384/lng-pipeline-terminal-govtto-decide-on-chinese-firms-bid-in-a-month/ 